\title{
Two Cases of Acute Subdural Hematoma of Arterial Origin
}

Tohru Soejima, Shinya OKuda, Shinichiro Wakisaka, Hajime Tokudda and Shigeaki MATSUOKA

Department of Neurosurgery, School of Medicine, University of Occupational and Environmental Health, Japan. Kitakyushu 807, Japan

\begin{abstract}
Two cases of acute subdural hematoma developed without severe head injury were reported. There was no cerebral contusion or laceration, and the only bleeding sources were pinholes in the walls of surface cortical arteries near the Sylvian fissure. Reports on acute subdural hematomas of arterial origin are reviewed and mechanism of the development of bleeding is discussed.
\end{abstract}

Key words: acute subdural hematoma, rupture of cortical artery.

(Received 14 November 1980)

\section{Introduction}

Acute subdural hematomas are commonly associated with laceration or contusion of the brain, or less frequently with an underlying vascular malformation (Bassett \& Lerman, 1952; Scott, 1949). Brisk bleeding from a pinpoint source in an otherwise normal artery on the cortical surface is reported rarely, and is mostly accompanied by head trauma (Drake, 1961; O'Brien et al., 1974). Those bleeding without injury were exceptional. In this paper, we present two further cases of acute subdural hematoma of arterial origin without definite head injury.

\section{Case Reports}

Case 1: A 69-year-old man had been treated for essential hypertension for more than ten years, but had had no experience of head trauma. On the day of admission, when he was strolling down a street, he suddenly suffered from severe headache followed by nausea and vomiting. On the way to the hospital, he became unconscious, and was admitted to our service about 7 hours after the onset of symptoms. Upon admission, he was semicomatous with anisocoria, larger on the left, left hemiparesis with hyperactive DTRs and positive Babinski's sign on the left. There was no scalp contusion or laceration. Plain skull x-ray films were normal. CT-scan showed a crescent shaped high density area over the left lateral convexity with collapsed left lateral ventricle and marked midline shift from the left to the right (Fig. 1). A left carotid angiogram revealed an avascular mass over the left cerebral hemisphere with midline shift. No aneurysm or arteriovenous 


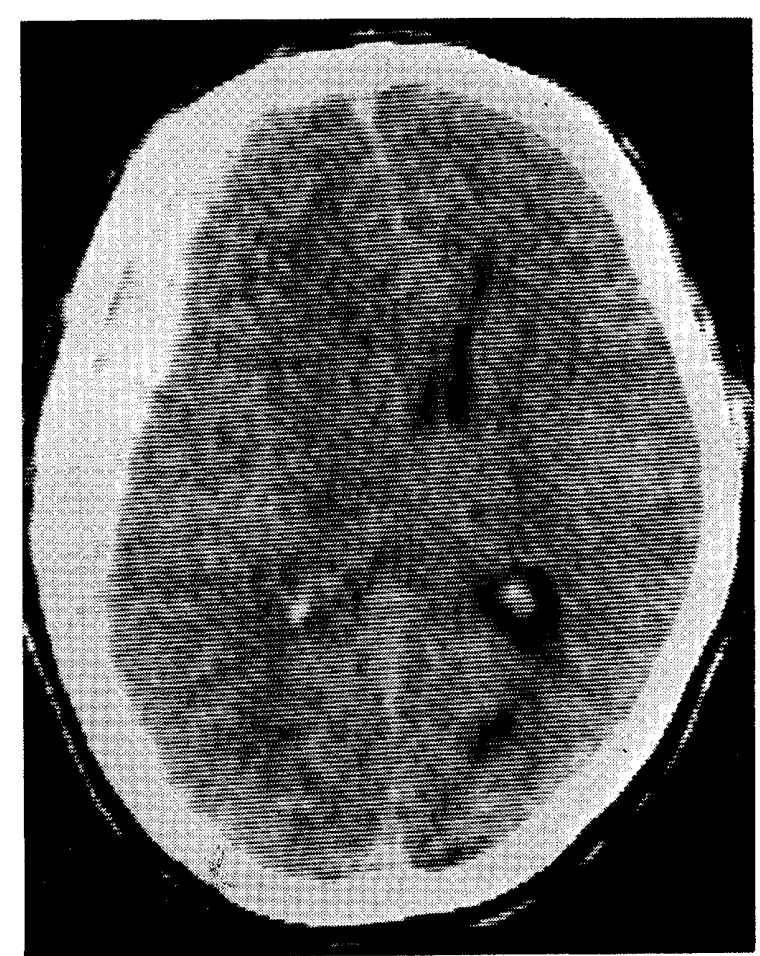

Fig. 1. Plain CT-scan of case 1 showing a crescent shaped high density area over the left cerebral convexity with marked midline shift.

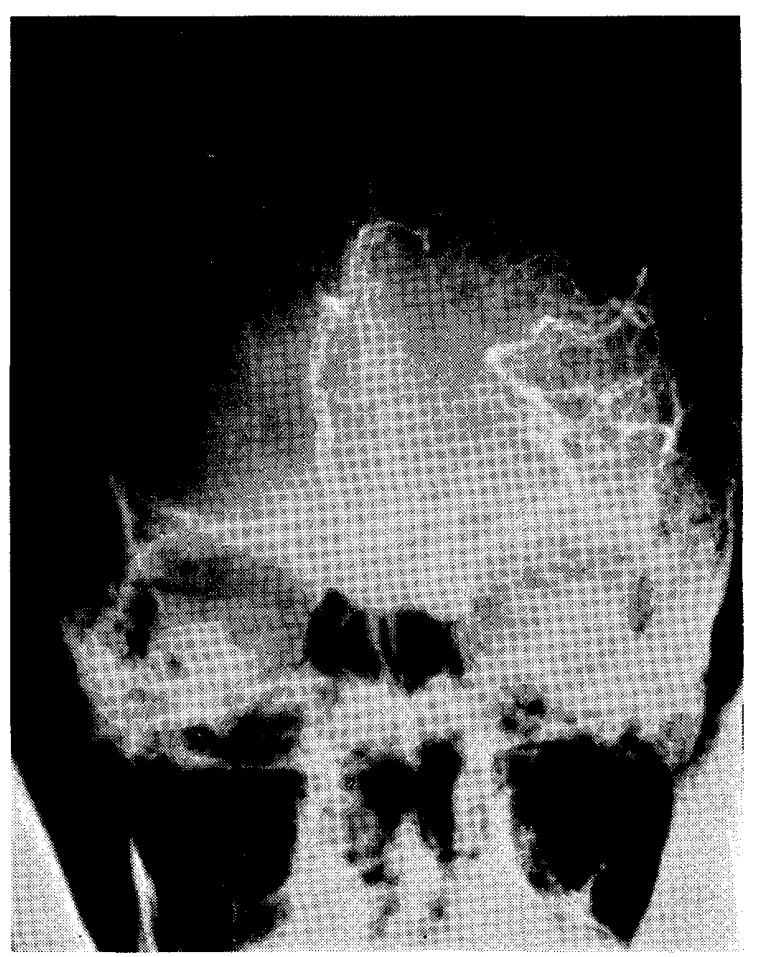

Fig. 2. Left carotid angiogram of case 1 showing an avascular area over the left cerebral convexity.

malformation was found (Fig. 2). Left fronto-parieto-temporal craniotomy was done on that day and a large amount of fresh blood clot was found in the subdural space. There was no abnormal membrane around the clot. Upon removal of the hematoma, a brisk and pulsating arterial bleeding occurred from a pinpoint opening in the lateral wall of the ascending frontal artery. The bleeding point was sealed with bipolar coagulation. There was no cerebral contusion or subarachnoid hemorrhage. Postoperative recovery was dramatic and the patient was discharged 2 weeks after the surgery without any neurological deficit.

Case 2: This 42-year-old laborer was alcoholic and had experienced some minor head traumas in the past few months. One evening when watching TV in a sitting posture, he suddenly suffered a clonic convulsive seizure starting from the right face and progressing to the whole body. Headache and speech difficulty followed. He had three other similar attacks in the following 2 days and these symptoms disappeared on the 4 th day. In the middle of the night six days after the initial episode, he suddenly had a severe headache followed by nausea and vomiting, and was admitted to the Neurological department of our University Hospital on the seventh day. Plain skull x-ray films were normal. After admission, his consciousness further deteriorated, decerebrate posture and bradycardia developed and both pupils dilated. After rapid intravenous infusion of mannitol, a left carotid angiography was done, revealing a large avascular area over the left cerebral 
hemisphere (Fig. 3). There was no aneurysm or arteriovenous malformation. Immediately prior to surgery, he was semicomatous with early papilledema, dilated and fixed pupils, bilateral hyperactive DTRs and positive Babinski's signs. With left parietal craniectomy, a large subdural hematoma was found. The hematoma had a thin outer membrane, but no inner membrane. The hematoma cavity was occupied with a small amount of partially liquefied clot and a large amount of fresh clot. As the clot was being removed, a fine stream of blood was seen pumping from a pinpoint opening of a cortical artery near the Sylvian fissure. This was considered the source of the subdural hemorrhage, and the bleeding was stopped by cautery. There was no contusion of the brain or subarachnoid hemorrhage. The postoperative course was uneventful and he was discharged 2 weeks later without neurological deficit.

\section{Discussion}

An acute subdural hematoma is usually regarded as a sequela of cerebral contusion or lacelation, and less frequently results from ruptured cerebral aneurysm or arteriovenous malformation bleeding directly into the subdural space (Bassett \& Lerman, 1952; Clark \& Walton, 1953). Spontaneous acute subdural hematoma unassociated with medical disorders such as those described above is very rare. Munro (1934) first described a 59year-old hypertensive woman, who was stricken with a sudden severe headache followed by left hemiparesis. Ten days after the ictus, he removed a large right subdural hematoma, but no source of hemorrhage was found. Scott (1949) reported 2 cases of spontaneous acute subdural hematoma. While no source of bleeding was found in one case, a fine stream of blood was found pumping from a pinpoint opening in the "Sylvian artery" after the removal of the clot in the other case. Since then, 8 cases of spontaneous

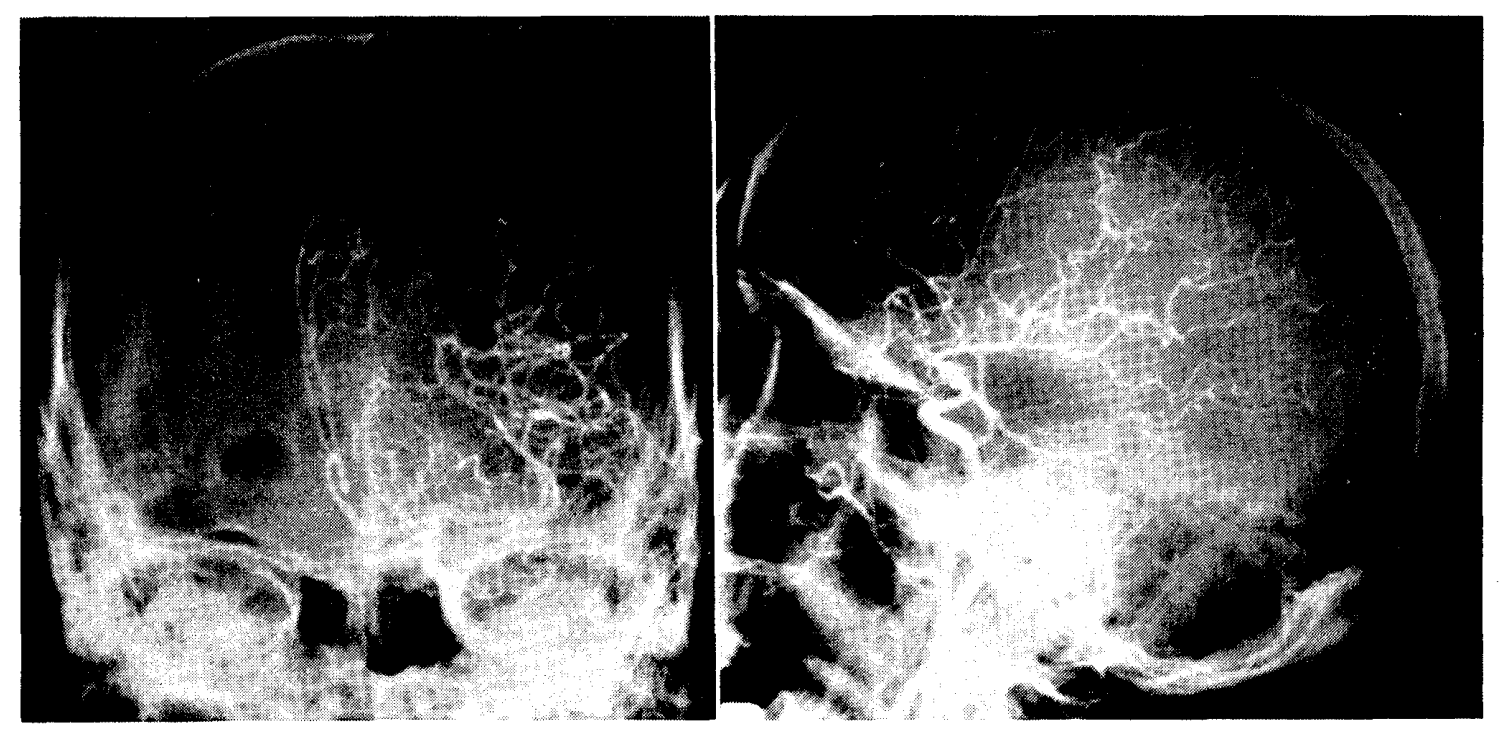

Fig. 3. Left carotid angiogram of case 2 showing a large avascular mass over the left cerebral hemisphere. 
Table 1. Acute subdural hematoma of arterial origin without head trauma

\begin{tabular}{|c|c|c|c|c|c|c|}
\hline Case & Authors & Age & Sex & Side & Allied disorder & Outcome \\
\hline 1 & Scott (1949) & 66 & M & $\mathrm{L}$ & none & alive \\
\hline 2 & Talalla \& McKissock (1971) & 61 & M & $\mathrm{R}$ & none & died \\
\hline 3 & "I & 54 & $\mathrm{M}$ & $\mathrm{R}$ & hypertension & died \\
\hline 4 & " & 57 & $\mathrm{M}$ & $\mathrm{R}$ & $?$ & died \\
\hline 5 & "l & 66 & $\mathrm{~F}$ & $\mathrm{R}$ & hypertension & died \\
\hline 6 & " & 54 & $\mathrm{M}$ & $\mathrm{L}$ & hypertension & alive \\
\hline 7 & " & 59 & $\mathrm{M}$ & $\mathrm{R}$ & none & died \\
\hline 8 & Byun \& Patel (1979) & 37 & $\mathrm{~F}$ & $\mathrm{R}$ & none & alive \\
\hline 9 & Soejima et al. (1981) & 69 & $\mathrm{M}$ & $\mathrm{L}$ & hypertension & alive \\
\hline 10 & $" \prime$ & 42 & $\mathrm{M}$ & $\mathrm{L}$ & alcoholism & alive \\
\hline
\end{tabular}

acute subdural hematoma originating from a surface cortical artery in relatively healthy individuals have been reported (Table 1). In the cases here reported, the bleeding sources in both were identical, and although trauma cannot be ruled out in the second case, there was no definite evidence of it. There are also case reports of acute subdural hematoma of arterial origin which followed head trauma (Vance, 1950; Krauland, 1956; Drake, 1961; O'Brien et al., 1974). All of Drake's 11 cases developed after very trivial head injury, and the streaming blood was found coming from a pinhole of a cortical artery near the Sylvian fissure, as was true in the present cases. No cerebral contusion was found. Vance reported 6 cases of subdural hematoma with arterial origin out of 102 autopsied cases. All had a history of head injury, and histological examination showed tears in the lateral walls of the surface cortical arteries. A frequent site of rupture was the junction of a surface artery with its perpendicular arterial twig, accompanied by tears in the arachnoid membrane. He also reported a thread-like filament attached to one side of the arterial opening, and this was histologically considered to be a segment of dura. O'Brien et al. (1974) histologically examined these holes in the bleeding arterial wall. They found no evidence of preexisting vascular disease. The adventitia of the ruptured vessel was fused with the arachnoid membrane, and there was a fibroblastic reaction in the adjacent adventitia appropriate to the period between the initiation of symptoms and the time of surgery. Judging from these findings, the very localized adhesions between the arachnoid and the adventitia of the cortical arteries or arterial twigs could develop by minimal provocation of unknown etiology (Byun \& Patel, 1979). And also it is not uncommon to find a fibrous adhesion between an arachnoid membrane or vessel and the dura during a craniotomy for other reasons. Minor motions of the brain could cause a shift between the brain and the dura resulting in tearing of both vessel wall and the arachnoid membrane at the site of adhesion, and subsequent hemorrhage into the subdural space.

As was demonstrated in our cases, this type of subdural hematoma is not accompanied by cortical damage which usually occurs in acute subdural hematoma in a severe head 
injury. Thus, when proper treatment is performed sufficiently early, the patient's recovery is excellent. The presence of this type of subdural hematoma should be widely recognized. Also, widespread use of CT-scan may increase the chance to discover this type of fulminating but benign subdural hematoma.

\section{Referrences}

Bassett, R. C. \& Lerman, L. J. (1952): Subdural hematoma associated with bleeding intracranial aneurysm. J. Neurosurg., 9: 433-450.

Byun, H. S. \& Patel, P. P. (1979): Spontaneous subdural hematoma of arterial origin: Report of two cases. Neurosurgery, 5: 611-613.

Clark, E. \& Walton, J. N. (1953): Subdural hematoma complicating intracranial aneurysm and angioma. Brain, 76: 378-404.

Drake, C. G. (1961): Subdural hematoma from arterial rupture. J. Neurosurg., 18: 597-601.

Krauland, W. (1956): Verletzungen der Schlagaderzweige an der Mantelfäche des Grosshirns durch stumpfe Gewalt ohne Schädelbruch als Quelle tödlicher subduraler Blutungen. Dtsch. Z. Nervenheilk., 175: 54-65.

Munro, D. (1934): The diagnosis and treatment of subdural hematomata: New Eng. J. Med., 210: $1145-1160$.

O'Brien, P. K., Norris, J. W. \& Tator, C. H. (1974): Acute subdural hematomas of arterial origin. J. Neurosurg. , 41: 435-439.

Scott, M. (1949): Spontaneous nontraumatic subdural hematomas. J. A. M. A., 141: 596601.

Talalla, A. \& McKissock, W. (1971): Acute "spontaneous" subdural hemorrhage. An unusual form of cerebrovascular accident. Neurology, 21: 19-25.

Vance, B. M. (1950): Ruptures of surface blood vessels on cerebral hemispheres as a cause of subdural hemorrhage. Arch. Surg., 61: 992-1006.

皮質動脈破綻による急性硬膜下血腫の 2 症例

副島徹・奥田 真也・枷坟 信一郎・德田元・松䦌 成明 率業医科大学脳神経外科教堂

要旨：明らかな外傷を認めない念性硬膜下血腫の 2 例を報告した。们れも術前検查や手術沂見か

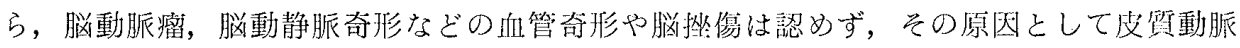

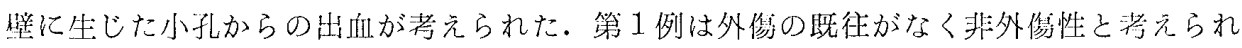
たが，第 2 例はアルコール中毒で，軽度の頭部打撲を経験したととがあり，外倠との関係

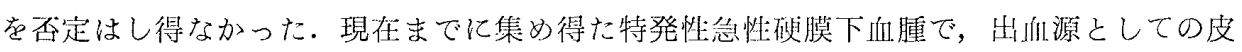

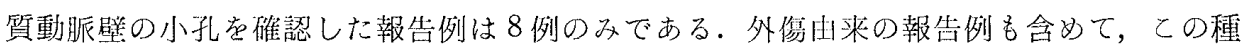
の急性硬膜下血腫をレビューし，血腫形成の機序について若下の検討を加えた。

J. UOEH (産栄安大誌), 3(1)：51-55 (1981) 